zeszyt 152, 2018, 33-53

doi: 10.4467/20833113PG.17.029.8252

Instytut Geografii i Gospodarki Przestrzennej UJ

Wydawnictwo Uniwersytetu Jagiellońskiego

\title{
POTENCJALNE I FUNKCJONALNE OBSZARY TURYSTYCZNE NA ROZTOCZU W ŚWIETLE WYNIKÓW WIELOWYMIAROWEJ ANALIZY PORÓWNAWCZEJ - WYZWANIA I PROBLEMY METODYCZNE
}

\author{
Teresa Bræezinska-Wójcik, Ewa Skowronek
}

\section{Potential and functional tourist areas in the Roztocze region in the light of the results of a multidimensional comparative analysis - methodological challenges and problems}

\begin{abstract}
The considerations presented below are part of current studies focused on touristic regionalisation methods. They attempt at developing a method for identification of tourist units (potential and functional areas) in the Roztocze region based on uniform criteria. The aim of the study was to initiate a discussion on methodological problems related to delimitation of touristic regions. This was achieved by a description and analysis of criteria applied currently in the touristic division of Roztocze and by a detailed assessment of potential and functions. Consequently, areas differing in their tourism potential and the degree of development of the tourism function have been distinguished. The obtained results indicate a necessity to continue the investigations of this issue, since delimitation of tourist regions remains a yet unresolved current problem. Therefore, it requires further studies, based in particular on modern techniques and research tools used in combination with various conceptual approaches.
\end{abstract}

Keywords: regionalisation method, tourism potential, tourism function, the Roztocze region

Zarys treści: Poniższe rozważania wpisują się w nurt prac poświęconych metodom regionalizacji turystycznej. Podjęto w nich próbę zaprezentowania metody wydzielania jednostek turystycznych (obszarów potencjalnych i funkcjonalnych) w regionie Roztocza na podstawie 
jednolitych kryteriów. Celem opracowania było ponadto zainicjowanie dyskusji nad problemami metodycznymi związanymi z delimitacją regionów turystycznych. Zamierzenia te zrealizowano poprzez przybliżenie i przeanalizowanie kryteriów dotychczasowych podziałów turystycznych Roztocza oraz wykonanie szczegółowych ocen potencjału i funkcji. Doprowadziły one do wyróżnienia na Roztoczu obszarów o zróżnicowanym potencjale turystycznym i różnym stopniu rozwoju funkcji turystycznej. Uzyskane wyniki badań wskazują na konieczność kontynuowania tej problematyki, gdyż zagadnienie delimitacji regionów turystycznych nadal jest aktualne i pozostaje nierozwiązane metodologicznie. Wymaga więc kolejnych prób, zwłaszcza z wykorzystaniem nowoczesnych technik i narzędzi badawczych oraz łączeniem różnych podejść koncepcyjnych.

Stowa kluczowe: metoda regionalizacji, potencjał turystyczny, funkcja turystyczna, Roztocze

\section{Wprowadzenie}

Poniższe rozważania wpisują się w nurt opracowań metodycznych związanych z delimitacją regionów turystycznych. Jest to problem trudny i nadal aktualny. Obszerny przegląd literatury przedmiotu w tym zakresie zawierają opracowania, m.in.: Dei (1982), Kruczka (2003), Derek (2008), Liszewskiego (2003, 2008, 2009), Durydiwki (2012), Sobotki (2014). Problem systematyki i klasyfikacji regionów turystycznych podejmowano także na łamach czasopism „Turyzm” (2003, t. 13, z. 1) oraz „Folia Turistica” (2009, t. 21). Istnieje również wiele opracowań (m.in. Filipowicz 1970; Plan kierunkowy... 1971; Wyrzykowski 1975; Bartkowski 1979, 1980; Leśko, Klementowski 1979), których analiza z punktu widzenia zastosowanych metod jest utrudniona z powodu niedostępności materiałów źródłowych oraz niepełnych opisów zastosowanych procedur.

Pierwsze polskie publikacje podejmujące problem wydzielania regionalnych jednostek turystycznych opierały się na inwentaryzacji, opisie i klasyfikacji zasobów przyrodniczych (np. klasyfikacja regionów uzdrowiskowych Leszczyckiego [1937] opracowana z wykorzystaniem metody bonitacji punktowej).

W latach 60. XX w. pojawiły się dwie regionalizacje turystyczne Polski autorstwa Mileskiej (1963) i Bajcara (1969a, b). Podstawowym kryterium oceny walorów turystycznych, podobnie jak u Leszczyckiego (1937), była w nich metoda bonitacji punktowej. Ponadto autorzy uwzględnili: wielkość bazy noclegowej i stopień jej wykorzystania oraz kierunki ruchu turystycznego określone na podstawie badań ankietowych. Uzyskane wyniki odniesiono do pól podstawowych, którymi były wyznaczone przez Kondrackiego (1960) jednostki krajobrazu naturalnego.

W latach 70. XX w. Bar i Doliński (1976) oraz Kruczek i Sacha (1977) w kolejnych podziałach wyróżnili regiony i rejony/podregiony turystyczne. W regionalizacji Bara i Dolińskiego wydzielono trzy regiony turystyczne oraz jednostki niższego rzędu, zwane Ziemiami, oraz rejony, nawiązujące do wspólnej historii i kultury obszarów. 
W podziale Kruczka i Sachy wyodrębniono 12 regionów i 48 podregionów, przyjmując ich granice za Kondrackim (1965). W obu opracowaniach za pomocą opisu, analizy i syntezy scharakteryzowano jednostki; nie uwzględniono żadnych mierników statystycznych.

W latach 80. XX w. Lijewski i in. (1985) zaproponowali dwustopniową regionalizację turystyczną Polski - regiony i rejony (wznawianą w kolejnych edycjach - do 2008 r.). W zakresie potencjału zinwentaryzowano walory wypoczynkowe, krajoznawcze (przyrodnicze i kulturowe), specjalistyczne, które stanowiły podstawę wyróżnienia miejscowości i obiektów turystycznych na potrzeby zagranicznej turystyki przyjazdowej. Zestawiono liczbę obiektów i miejsc noclegowych w jednostkach administracyjnych różnej rangi. Ponadto zinwentaryzowano bazę gastronomiczną według województw oraz rodzajów obiektów, a także wybrane elementy bazy towarzyszącej. Uwzględniono również turystyczną infrastrukturę transportową. W zakresie funkcjonalnego wykorzystania przestrzeni podjęto próbę analizy wielkości, struktury i rozmieszczenia ruchu turystycznego. Mimo zestawienia bardzo wielu danych autorzy nie określili dokładnego przebiegu granic wyróżnionych jednostek ze względu na „umowny ich przebieg”. Nowym elementem opracowania, z kartograficznego punktu widzenia, było zamieszczenie - na dołączonej do opracowania mapie - diagramów kołowych, prezentujących liczbę miejsc noclegowych w gminach, które autorzy określili jako turystyczne. Istotne było również wydzielenie ważniejszych miejscowości krajoznawczych na podstawie liczby zestawionych walorów.

Na początku XXI w. zarysowały się dwie koncepcje w zakresie wyróżniania regionów turystycznych. W pierwszym nurcie - w pracach autorstwa Kaprowskiego (2004), Mazura (2005) oraz Cabaja i Kruczka (2007) - podzielono Polskę na makroregiony, regiony i podregiony turystyczne w nawiązaniu do głównych krain geograficznych Polski, podobnie jak we wcześniejszych opracowaniach. W drugim Kruczek (2003) zaproponował podział Polski na makroregiony i regiony turystyczne, nawiązujący do jednostek administracyjnych. Jako makroregiony wyróżnił zgrupowania województw na podstawie przesłanek historycznych lub semantycznych. Za regiony uznał województwa. Podział ten jest prosty w użytkowaniu z metodycznego i edukacyjnego punktu widzenia. Umożliwia porównania ilościowe (np. bazy turystycznej, ruchu turystycznego), obliczanie różnych wskaźników oraz analizy porównawcze w wydzielonych jednostkach (Kruczek, Zmyślony 2010). Był on popularyzowany w kolejnych wydaniach podręcznika Polska. Geografia atrakcji turystycznych - 2003, 2006, 2007, 2008, 2009, 2010, 2011.

W pierwszych dekadach XXI w. zmieniło się także podejście koncepcyjne do wyróżniania jednostek regionalnych. $Z$ dotychczasowego, opartego tylko na analizach cech środowiska przyrodniczego, nastąpiło przejście do ujęć funkcjonalnych (np. uwzględniających różnorodne wskaźniki ruchu turystycznego). W tym nurcie, w 2009 r., Liszewski opracował koncepcję regionalizacji turystycznej Polski, której 
podstawą były wartości syntetycznego miernika funkcji turystycznej odniesione do różnych jednostek przestrzennych. Uzyskano je w rezultacie kompleksowej analizy ruchu turystycznego obejmującej: wielkość, sezonowość, strukturę demograficzną i społeczną oraz cele i zasięg geograficzny.

W 2014 r. Sobotka opracował podział Polski na obszary o najwyższym stopniu wykorzystania turystycznego. Kryterium stanowiła liczba miejsc noclegowych odniesionych do powierzchni gminy. Ponadto wydzielenia turystycznych jednostek regionalnych pojawiały się niezależnie w opracowaniach podejmujących kompleksowe oceny funkcjonowania przestrzeni geograficznej Polski, w tym obszarów wiejskich (m.in. Bański, Stola 2002; Derek 2008; Durydiwka 2012). Zastosowano w nich różne podejścia metodyczne.

Równolegle do regionalizacji turystycznych Polski opracowywano podziały odnoszące się do mniejszych obszarów, np. Karpat, regionu łódzkiego, Doliny Odry. Do ich przygotowania zastosowano różne kryteria: występowanie walorów turystycznych oraz elementów stanowiących podstawę do określenia funkcji turystycznej (miejsca noclegowe i koncentracje ruchu turystycznego) (Groch i in. 2000, za Ptaszycka-Jackowska 2007; Zawilińska 2005); percepcję miejscowości turystycznych metodą kwestionariuszową (Matczak 1995); atrakcyjność turystyczną gmin z zastosowaniem wskaźnika syntetycznego (Włodarczyk 2003). W tej grupie znalazły się również prace dotyczące regionalizacji Roztocza.

Głównymi celami niniejszego opracowania są: zaprezentowanie metody wydzielania jednostek turystycznych w regionie Roztocza na podstawie jednolitych kryteriów oraz zainicjowanie dyskusji nad problemami metodycznymi związanymi z ich delimitacją. Założone cele zrealizowano poprzez przybliżenie zasad i kryteriów dotychczasowych podziałów turystycznych Roztocza oraz wykonanie szczegółowych ocen potencjału i funkcji jako podstawy zaproponowanej regionalizacji turystycznej.

Zastosowana metoda jest istotna z punktu widzenia łączenia podejśc koncepcyjnych opartych z jednej strony na analizach cech środowiska przyrodniczego, z drugiej zaś - na analizach potencjału i funkcji turystycznej. Dodatkowo istotne jest zastosowanie jednolitej procedury badawczej do wyróżniania jednostek turystycznych.

\section{Dotychczasowe próby turystycznej regionalizacji Roztocza}

Roztocze jako region turystyczny pojawia się w opracowaniach kilku autorów (Karolczak 2002; Tucki 2009; Świeca i in. 2015; Brzezińska-Wójcik i in. 2016).

Karolczak (2002) w regionie Roztocza wydzieliła rejony turystyczne: Zwierzyniecko-Szczebrzeszyński, Krasnobrodzki, Józefowski, Susiecko-Narolski, Tomaszowski, Horyniecki. Zastosowała w tym celu metodę bonitacji punktowej dla pól podstawowych (kwadraty o powierzchni $25 \mathrm{~km}^{2}$ ). Następnie - opierając się na dwóch 
kategoriach wyznaczników: potencjalnym (walory, dostępność, uwarunkowania społeczno-ekonomiczne) i realnym (zagospodarowanie i ruch turystyczny) - wyróżniła podprzestrzenie turystyczno-wypoczynkowe - eksploracji, penetracji, asymilacji, kolonizacji.

W 2009 r. Tucki w regionalizacji turystycznej województwa lubelskiego, na podstawie wielkości liczbowych Syntetycznego Miernika Atrakcyjności Turystycznej (SMAT) obliczonego dla gmin, wyróżnił w granicach Roztocza Region turystyczny I.A. obejmujący 10 gmin (Bełżec, Susiec, Józefów, Krasnobród, Zwierzyniec, Tomaszów Lubelski, Adamów, Tarnawatka, Lubycza Królewska, Tereszpol) oraz miasto Tomaszów Lubelski.

W 2015 r. podjęto próbę opracowania kompleksowej regionalizacji turystycznej Roztocza w granicach Polski i Ukrainy (Świeca i in. 2015). Jej podstawę stanowiły: wskazanie obszarów o długotrwałym rozwoju zjawisk turystycznych; charakterystyka przestrzennego rozmieszczenia zasobów turystycznych; ocena zróżnicowania atrakcyjności turystycznej gmin Roztocza w świetle wskaźników SMAT przeprowadzona przez Tuckiego (2009); ocena aktywności władz samorządowych i stowarzyszeń w rozwoju turystyki przygotowana przez Tuckiego i Świecę (2008); wykorzystanie obiektów zbiorowego zakwaterowania (liczba korzystających z noclegów ogółem i liczba udzielonych noclegów ogółem) w gminach Roztocza oraz liczba turystów odwiedzających obiekty/miejsca w 2014 r. W rezultacie wyróżniono 5 subregionów i 21 obszarów (16 funkcjonalnych i 5 perspektywicznych) oraz główne miejscowości turystyczne.

Próbę ujednolicenia kryteriów wydzielenia turystycznych obszarów potencjalnych i funkcjonalnych na Roztoczu w granicach Polski podjęto rok później (Brzezińska-Wójcik i in. 2016). Tym, co obok zasięgu przestrzennego, różniło kryteria zastosowane do podziału, były wskaźniki atrakcyjności turystycznej SMAT obliczone dla 30 gmin na podstawie danych z lat 2014-2015. Wyróżniono 4 subregiony oraz 13 obszarów turystycznych (8 funkcjonalnych i 5 perspektywicznych), a ponadto główne miejscowości turystyczne.

W podjętych opracowaniach nie koncentrowano się jednak na szczegółowej analizie cech, przeprowadzonej z zastosowaniem jednolitej procedury badawczej, dlatego zasadne było podjęcie próby takiej oceny $-\mathrm{z}$ jednej strony potencjału turystycznego, z drugiej zaś funkcji turystycznej dla gmin w granicach Roztocza.

\section{Metody badań i źródła danych}

Przyjęta procedura badawcza obejmowała następujące etapy: wyróżnienie jednostek powierzchniowych - subregionów: gorajskiego, szczebrzeszyńskiego, tomaszowskiego, rawskiego (Brzezińska-Wójcik i in. 2016), w nawiązaniu do jednostek geomorfologicznych (ryc. 1); oszacowanie potencjału turystycznego za pomocą 
Syntetycznego Miernika Potencjału Turystycznego (SMPT); określenie stopnia rozwoju funkcji turystycznej z wykorzystaniem Syntetycznego Miernika Funkcji Turystycznej (SMFT); wydzielenie obszarów turystycznych (potencjalnych i funkcjonalnych).

W niniejszym opracowaniu przyjęto - w nawiązaniu do Naumowicz (1993) - że potencjał turystyczny obejmuje elementy składowe, takie jak: walory przyrodnicze i kulturowe, zagospodarowanie turystyczne, aktywność samorządów lokalnych na rzecz turystyki i rekreacji. Stopień rozwoju funkcji turystycznej - podobnie jak Warszyńska i Jackowski (1979), Jackowski (1981) oraz Matczak (1989) - określono na podstawie liczby osób korzystających z noclegów ogółem oraz intensywności ruchu turystycznego.

Założeniem metodycznym było zastosowanie jednolitej procedury do wyróżnienia powierzchniowych jednostek turystycznych (m.in. Jafari 2001). Istotne są przy tym dostępne źródła danych (GUS). Dlatego liczbowe wielkości przyjętych cech diagnostycznych odniesiono do 30 gmin, których obszar w przynajmniej 10 procentach znajduje się na Roztoczu, uwzględniając ich położenie w granicach poszczególnych subregionów.

W procedurze badawczej zastosowano taksonomiczną metodę wielowymiarowej analizy porównawczej, zaadoptowaną za Gołembskim (1999). Umożliwiła ona wymierne porównanie z sobą obiektów wielocechowych, przy wykorzystaniu sumarycznego wskaźnika cech. Wielkości liczbowe dwóch przyjętych składowych (potencjału i funkcji) odniesiono do określonej jednostki miary, tj. do powierzchni każdej z gmin. W rezultacie obliczono wyżej wymienione wskaźniki (SMPT, SMFT). Ich wielkości, zgrupowane w przedziały klasowe, pozwoliły na wyróżnienie potencjalnych i funkcjonalnych obszarów turystycznych (gmin) w subregionach Roztocza. Podkreślić należy, że z punktu widzenia jakości wyników i ich interpretacji istotne jest stosowanie jednolitych metod statystycznych do klasyfikowania danych, w tym zwłaszcza przedziałów klasowych. Jednakże w tym zakresie, w literaturze przedmiotu (m.in. Pociecha i in. 1988; Pasławski 2003; Leonowicz 2006; Pociecha 2008), nie wypracowano jeszcze jednolitej procedury. $Z$ punktu widzenia przedstawiania zależności zjawisk granice przedziałów klasowych powinny być, według m.in. Evansa (1977), odniesione do zbioru wartości w jednakowy sposób. Możliwości takie, zdaniem tego autora, daje zastosowanie następujących metod: kwantyli, metody opartej na średniej arytmetycznej, metody wielokrotności odchylenia standardowego i granic naturalnych. Dlatego, do uzyskania wyników zaprezentowanych w niniejszej pracy, zastosowano metodę średnich arytmetycznych, która daje jednoznaczne i porównywalne odniesienie granic klas do zbioru wartości. W ostatnim zaś etapie - metodę wielokrotności odchylenia standardowego, która umożliwiła wyznaczenie klas o porównywalnym odchyleniu od średniej arytmetycznej dla każdego zbioru danych.

Wizualizację uzyskanych wyników wykonano z zastosowaniem standardowych narzędzi GIS. 


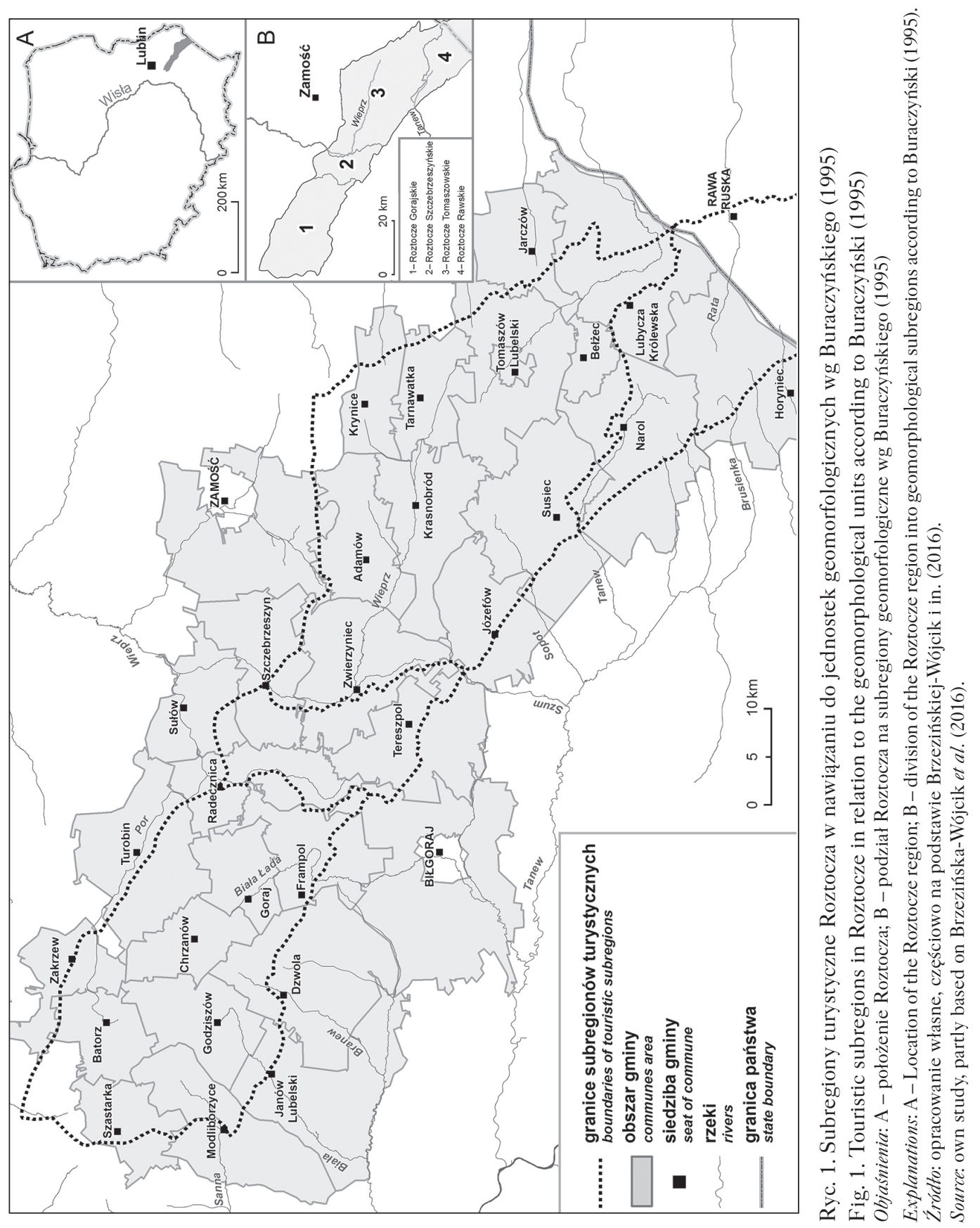




\section{Określenie potencjału turystycznego}

Do oceny potencjału każdej analizowanej gminy za pomocą Syntetycznego Miernika Potencjału Turystycznego (SMPT) przyjęto 45 cech diagnostycznych pogrupowanych w sześć działów. Pierwszy dział stanowiły krajoznawcze walory przyrodnicze (17 cech: osobliwości flory; skałki i grupy skał; wąwozy; doliny i przełomy rzek; źródliska; wodospady - progi; jaskinie; głazy narzutowe; kamieniołomy; odsłonięcia; stanowiska ze skrzemieniałym drewnem; wydmy; parki zabytkowe; muzea i zbiory przyrodnicze; punkty widokowe; parki narodowe; parki krajobrazowe). Do działu drugiego zaliczono krajoznawcze walory kulturowe (11 cech: grodziska; zabytkowe układy urbanistyczne; zabytkowe układy ruralistyczne; kościoły oraz zespoły kościelne i klasztorne; cerkwie i zespoły cerkiewne; synagogi; kaplice i kapliczki oraz krzyże przydrożne; cmentarze; zespoły zamkowe i pałacowe oraz dworskie; obiekty użyteczności publicznej; obiekty techniczne i przemysłowe). Trzeci dział stanowiła baza noclegowa (3 cechy: obiekty zbiorowego zakwaterowania; pokoje gościnne; kwatery agroturystyczne), czwarty - baza gastronomiczna (8 cech: restauracje; bary; karczmy; kawiarnie; pizzerie; stołówki; zajazdy; inne), piąty zaś - dostępność komunikacyjna (cechy - drogi: krajowe, wojewódzkie, powiatowe i gminne). Szósty dział stanowiła aktywność samorządów lokalnych w zakresie turystyki (3 cechy: organizacja i zarządzanie rozwojem turystyki w gminie, promocja i informacja oraz współpraca).

W konsekwencji dla każdego z działów obliczono syntetyczne mierniki potencjału, nazwane odpowiednio: SMPP (Syntetyczny Miernik Potencjału Przyrodniczego), SMPK (Syntetyczny Miernik Potencjału Kulturowego), SMPBN (Syntetyczny Miernik Potencjału Bazy Noclegowej), SMPBG (Syntetyczny Miernik Potencjału Bazy Gastronomicznej), SMDDK (Syntetyczny Miernik Drogowej Dostępności Komunikacyjnej), SMAWG (Syntetyczny Miernik Aktywności Władz Gminnych) (ryc. 2A-F). Etap zakończono obliczeniem ogólnego Syntetycznego Miernika Potencjału Turystycznego (SMPT) dla każdej gminy (tab. 1; ryc. 4).

\section{Określenie funkcji turystyeznej}

Na kolejnym etapie obliczono ogólny Syntetyczny Miernik Funkcji Turystycznej (SMFT) w 30 gminach w granicach regionu. Do oceny funkcji każdej spośród nich przyjęto 2 działy. Pierwszy stanowiła liczba osób korzystających z noclegów ogółem, drugi zaś - liczba turystów odwiedzających obiekty/miejsca, miejscowości. Na tym etapie postępowania nie było możliwe wykorzystanie jednolitych źródeł danych. Dlatego wielkości w pierwszym dziale uzyskano z Banku Danych Lokalnych (BDL 2016), a dotyczące ruchu turystycznego - z konkretnych miejsc, obiektów i wydarzeń z roku 2015. Do określenia funkcji turystycznej na Roztoczu nie zastosowano klasycznych wskaźników (np. Baretje’a-Deferta), gdyż osiągnęłyby one wielkości 
bardzo małe i trudne do wykorzystania w analizie porównawczej gmin. Utrudniłoby to znacząco określenie stopnia zróżnicowania funkcji turystycznej w roztoczańskich jednostkach administracyjnych. Podobną opinię wyraża Derek (2008).

W konsekwencji dla każdego z działów obliczono syntetyczne mierniki funkcji, odpowiednio: SMKMO, SMOOM (ryc. 3A-B). Na tym etapie postępowanie zakończono obliczeniem ogólnego Syntetycznego Miernika Funkcji Turystycznej (SMFT) dla każdej gminy (tab. 2; ryc. 4).

\section{Ocena stopnia wykorzystania potencjału turystycznego}

W celu wyróżnienia potencjalnych i funkcjonalnych obszarów turystycznych przeanalizowano uzyskane wielkości wskaźników SMPT i SMFT w gminach. Uporządkowano je w cztery przedziały klasowe za pomocą grupowania danych statystycznych w szereg rozdzielczy przedziałowy (statystyka opisowa). Następnie wielkości obu ogólnych mierników syntetycznych (SMPT i SMFT) odniesiono do przestrzeni dwuwymiarowej (ryc. 4).

Uwzględniając wielkości wskaźników ogólnych SMPT i SMFT w gminach, za pomocą metody podziału naturalnego na klasy (Pasławski 2003), w obu kategoriach wyróżniono po dwa przedziały klasowe porządkujące gminy (obszary turystyczne) w dwa podzbiory - potencjalny i funkcjonalny. Na tej podstawie wyróżniono potencjalne obszary turystyczne (gminy, dla których wielkości SMPT $\leq 0,370$; SMFT $\leq 0,261$ ) oraz funkcjonalne (gminy z SMPT > 0,370; SMFT > 0,261) (ryc. 4).

\section{Źródła danych}

W pierwszym etapie przestudiowano wtórne źródła danych. Informacje o rodzaju, liczebności i przestrzennym rozmieszczeniu walorów turystycznych, wielkości oraz stanie zagospodarowania turystycznego w granicach Roztocza, zebrano w latach 2014-2016 w trakcie badań terenowych.

W związku z koniecznością porównywalności otrzymanych wyników SMPT i SMFT dla całego zbioru danych informacje o cechach uwzględnionych w badaniach ( $\mathrm{z}$ uwagi na przyjęte pole podstawowe - gminę), pochodziły ze zbioru Banku Danych Lokalnych (BDL) GUS. Ponadto informacje o niektórych cechach uzyskano w oddziałach PTTK w Lublinie i Zamościu, w dyrekcji Roztoczańskiego Parku Narodowego, w dyrekcjach i zarządach parków krajobrazowych oraz dróg publicznych, a także w inspektoratach ochrony środowiska. Pozyskano je również z domowych stron internetowych gmin i materiałów reklamowych.

Zagadnienie ruchu turystycznego w regionie przeanalizowano przede wszystkim na podstawie jego natężenia, zarejestrowanego w obiektach zbiorowego zakwaterowania w 30 gminach, w roku 2014 (stat.gov.pl/bdl). Dodatkowo uwzględniono: 
liczbę sprzedanych biletów wstępu do Roztoczańskiego Parku Narodowego (RPN); wyniki z czujników pyro-elektrycznych zainstalowanych w RPN oraz przy ścieżkach edukacyjnych w rezerwatach Czartowe Pole i Nad Tanwią (Świeca i in. 2015); informacje uzyskane bezpośrednio od gestorów obiektów (Chrzanów, Batorz, Jacnia) oraz organizatorów wydarzeń turystycznych (w tym m.in. rajdów); ewidencje prowadzone w urzędach gmin (Janów Lubelski, Radecznica, Szczebrzeszyn, Krasnobród, Józefów, Tomaszów Lubelski, Horyniec) i w muzeach (Guciów, Bełżec, Siedliska); dane LOT Roztocze i ze stron internetowych PTTK (http://www.zamosc.pttk.pl/ wordpress/?page_id=7804 - 4.02.2017).

\section{Funkcjonalne i potencjalne obszary w turystycznym regionie Roztocza}

Funkcjonalne i potencjalne obszary turystyczne na Roztoczu wyróżniono na podstawie uzyskanych wielkości syntetycznych mierników potencjału i funkcji.

W odniesieniu do potencjału - dla każdego z sześciu działów obliczono syntetyczne mierniki potencjału, nazwane odpowiednio: SMPP, SMPK, SMPBN, SMPBG, SMDDK, SMAWG (ryc. 2A-F).

W konsekwencji uzyskano wielkości ogólnego Syntetycznego Miernika Potencjału Turystycznego (SMPT) dla każdej gminy (tab. 1).

\section{$\longrightarrow$}

Ryc. 2. Przestrzenne zróżnicowanie potencjału turystycznego w gminach Roztocza Fig. 2. Spatial diversity of tourist potential in the Roztocze communes

Objaśnienia: A - przyrodniczego w świetle Syntetycznego Miernika Potencjału Przyrodniczego (SMPP); B - kulturowego w świetle Syntetycznego Miernika Potencjału Kulturowego (SMPK); C-bazy noclegowej w świetle Syntetycznego Miernika Potencjału Bazy Noclegowej (SMPBN); D - bazy gastronomicznej w świetle Syntetycznego Miernika Potencjału Bazy Gastronomicznej (SMPBG); E - dostępności komunikacyjnej w gminach Roztocza w świetle Syntetycznego Miernika Drogowej Dostępności Komunikacyjnej (SMDDK); F - aktywności samorządów lokalnych na Roztoczu w świetle wielkości Syntetycznego Miernika Aktywności Władz Gminnych (SMAWG).

Explanations: A - natural potential in the light of the Synthetic Measure of Nature Potential (SMNP); B - cultural potential in the light of the Synthetic Measure of Culture Potential (SMCP); G - accommodation facilities in the light of the Synthetic Measure of Accommodation Facility Potential (SMAFP); D - catering facilities in the light of the Synthetic Measure of Catering Facility Potential (SMCFP); E - transport accessibility in Roztocze communes in the light of the Synthetic Measure of Transport Accessibility Potential (SMTAP); F - activity of local governments in Roztocze in the light of the Synthetic Measure of Commune Government Activity Potential (SMCGA). 


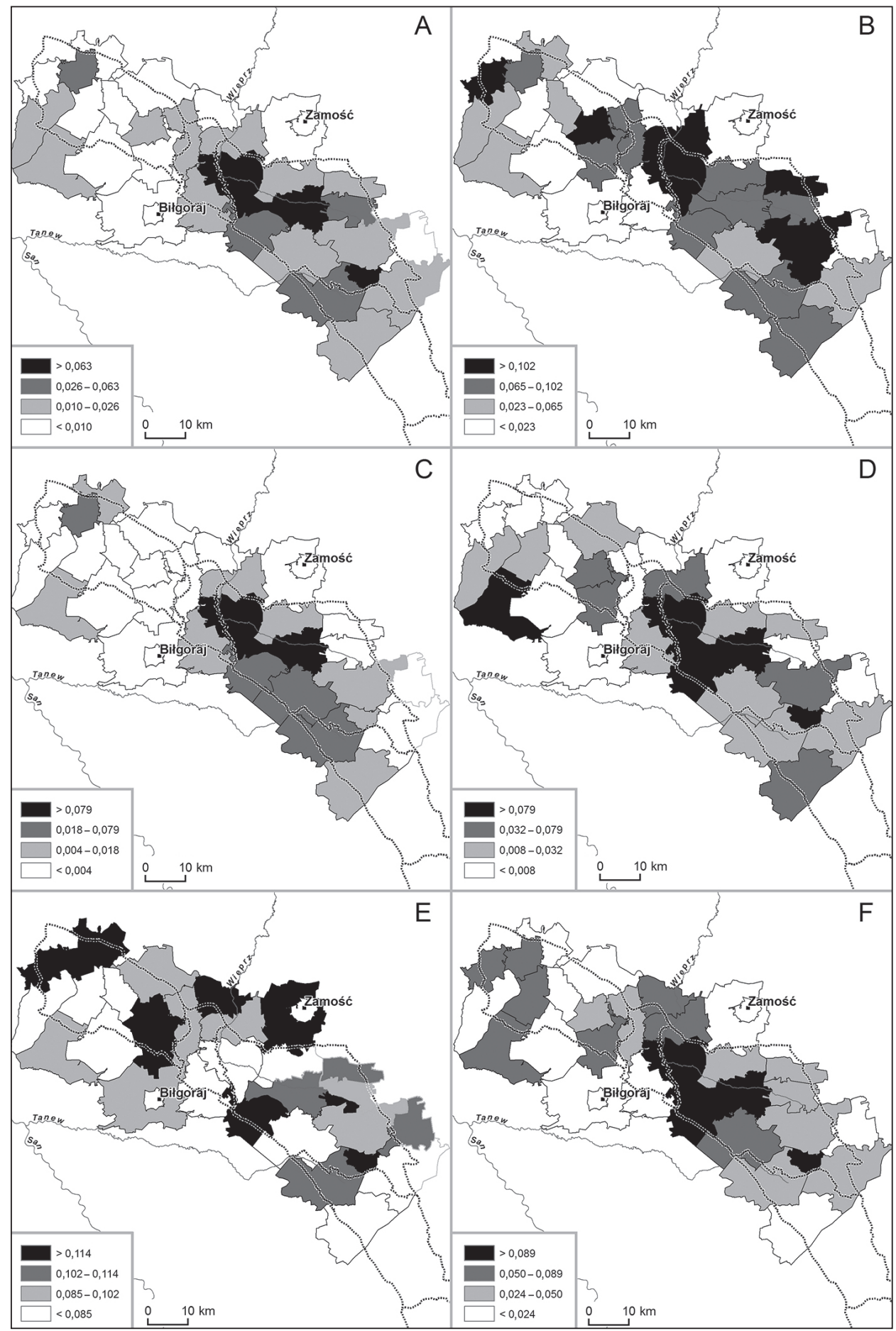




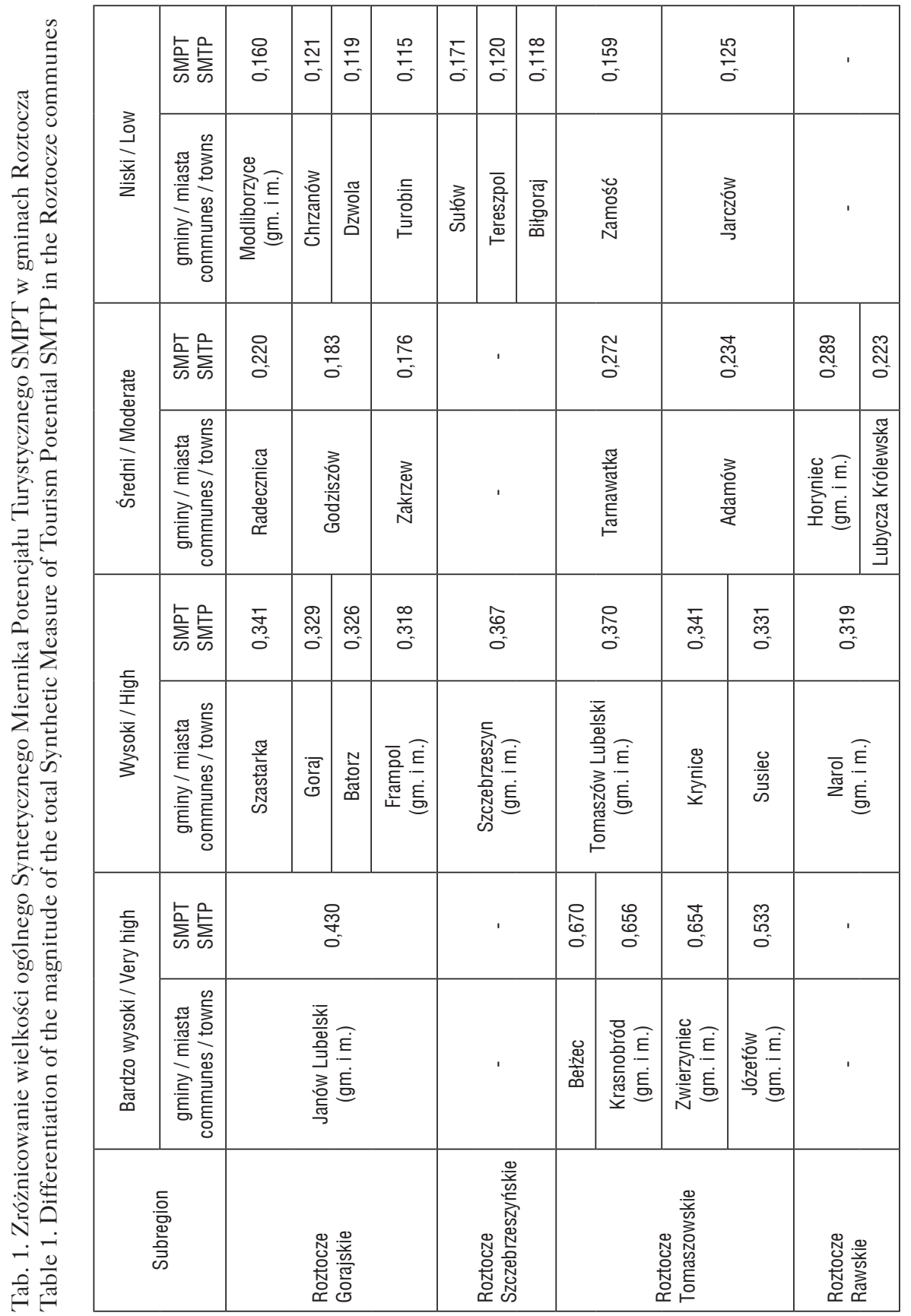


Wielkości liczbowe SMPT uzyskane dla gmin sklasyfikowano w cztery kategorie potencjału: „bardzo wysoki” (>0,425), „wysoki” $(0,290-0,425)$, „średni” $(0,175-0,290)$ i „niski” $(<0,175)$ (ryc. 4).

W odniesieniu do funkcji - dla każdego z dwóch działów obliczono wskaźniki SMKMO i SMOOM (ryc. 3A-B).

W kolejnym etapie obliczono ogólny Syntetyczny Miernik Funkcji Turystycznej (SMFT) dla każdej gminy (tab. 2).

Wielkości liczbowe SMFT pozwoliły na wyróżnienie gmin o funkcji turystycznej rozwiniętej: „bardzo dobrze” (> 0,442), „dobrze” $(0,132-0,442)$, „średnio” (0,019-0,132), „słabo/brak” (<0,019) (ryc. 4).

Na podstawie przyjętych wielkości wskaźników (SMPT >0,370, SMFT > 0,261) wyodrębniono 9 turystycznych obszarów funkcjonalnych - gmin: Janów Lubelski (subregion gorajski), Szczebrzeszyn (subregion szczebrzeszyński), Zwierzyniec, Krasnobród, Bełżec, Susiec, Tomaszów Lubelski, Józefów (subregion tomaszowski), Horyniec (subregion rawski). Pozostałe 21 gmin, z wartościami wskaźników mieszczących się w przedziałach $\mathrm{SMPT} \leq 0,370$, SMFT $\leq 0,261$ ), uznano za potencjalne obszary turystyczne. Są to gminy: Batorz, Chrzanów, Dzwola, Frampol, Godziszów,

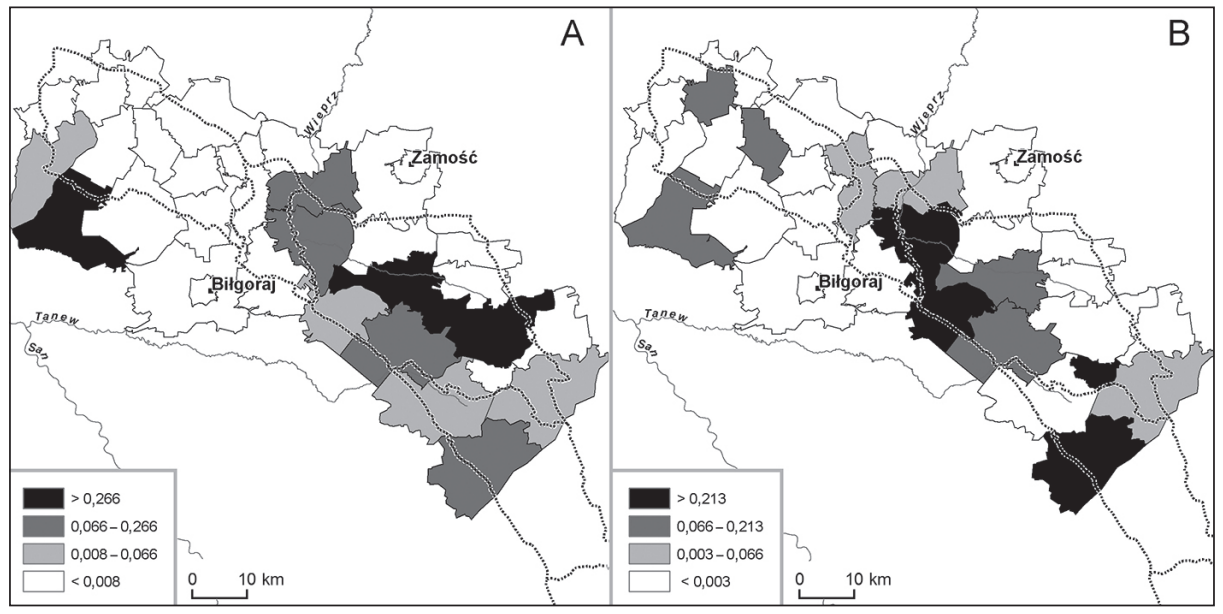

Ryc. 3. Przestrzenne zróżnicowanie funkcji turystycznej w gminach Roztocza Fig. 3. Spatial diversity of the tourism function in the Roztocze communes Objaśnienia: A - na podstawie Syntetycznego Miernika Korzystających z Noclegów Ogółem (SMKNO); B - na podstawie Syntetycznego Miernika Odwiedzających Obiekty/Miejsca (SMOOM).

Explanations: A - based on the Synthetic Measure of Total Accommodation Users (SMTAU); B - based on the Synthetic Measure of Object/Site Visitors (SMOSV). 


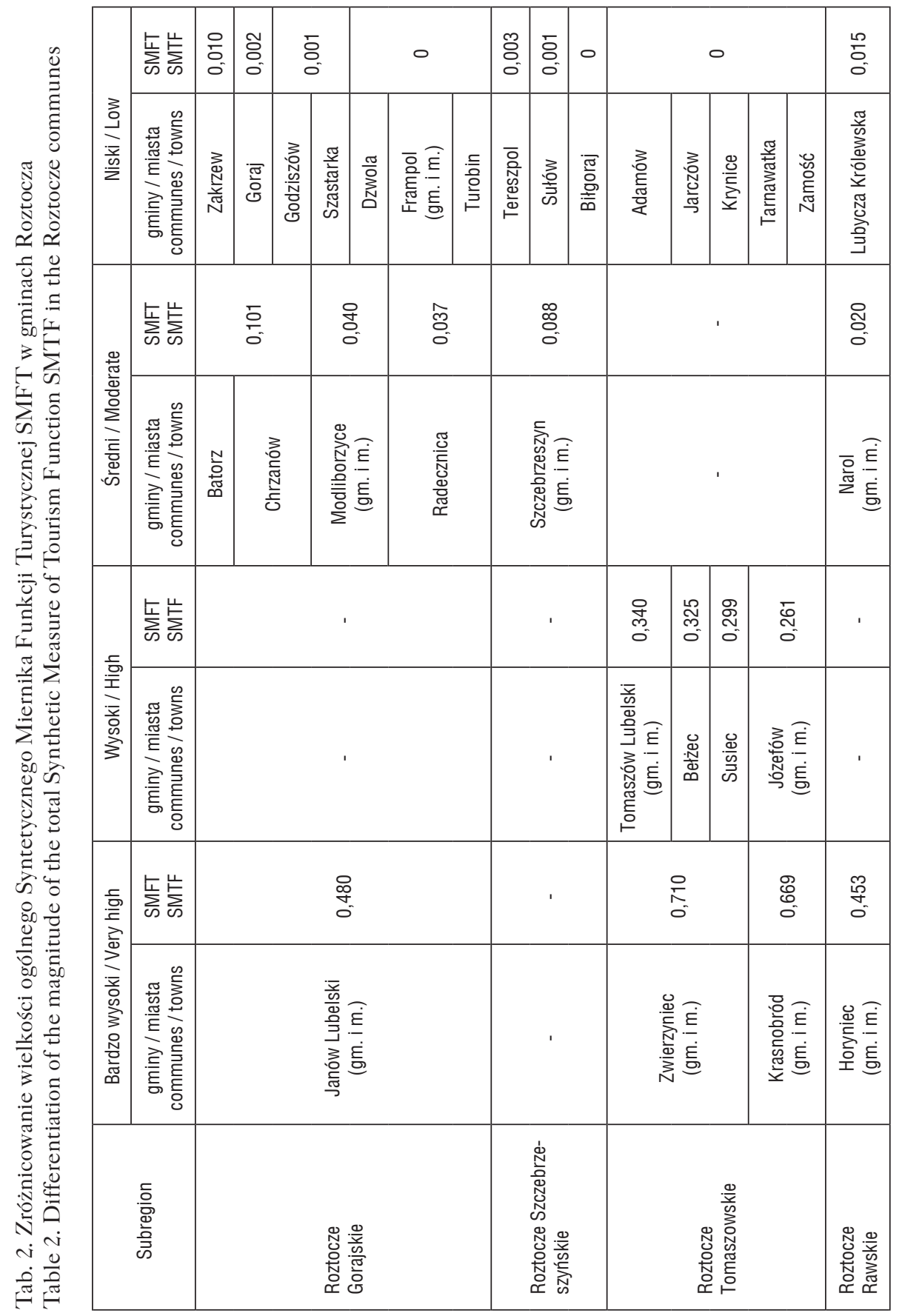




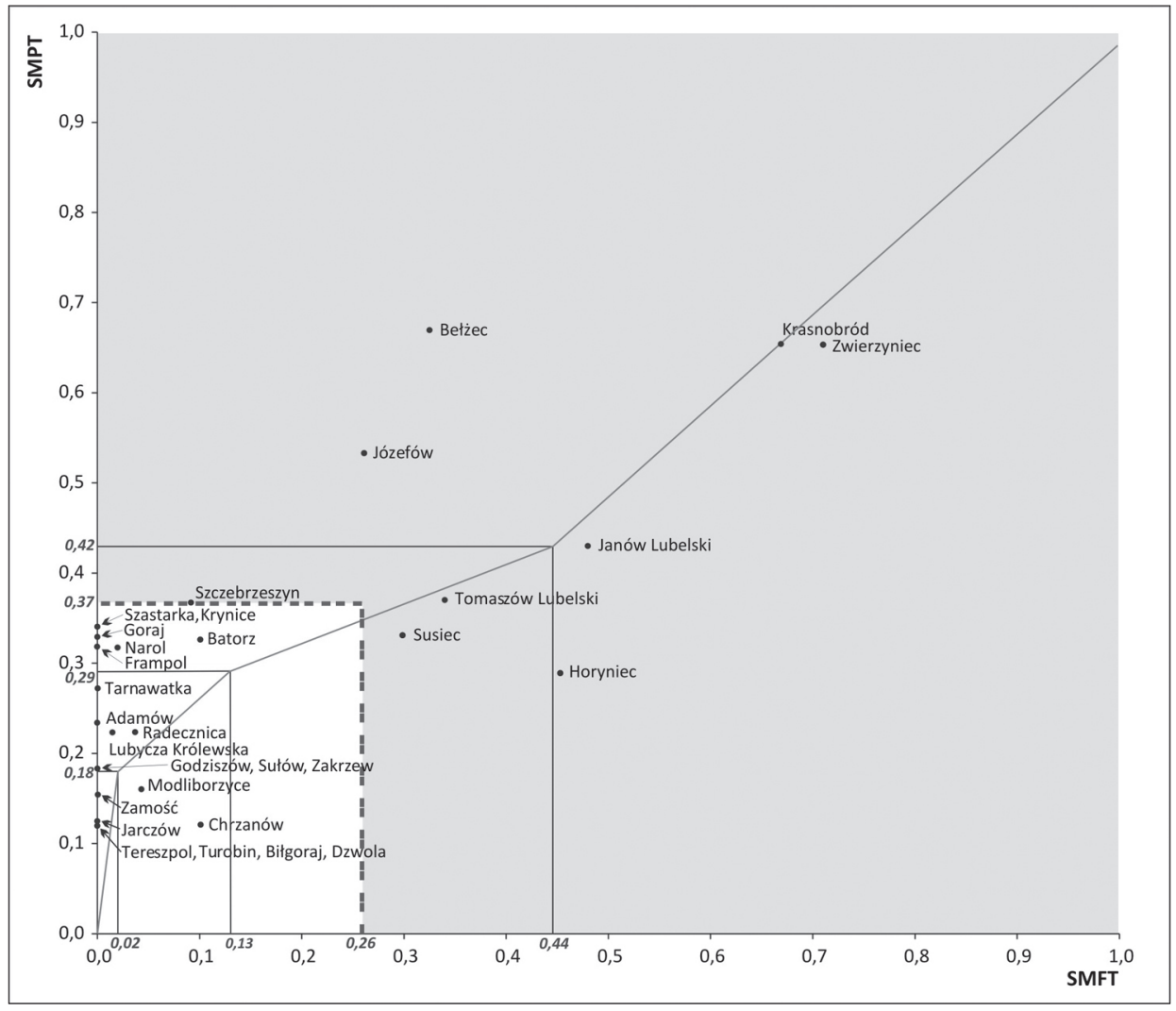

Ryc. 4. Lokalizacja roztoczańskich gmin w dwuwymiarowej przestrzeni ogólnych wskaźników potencjału turystycznego (SMPT) i funkcji turystycznej (SMFT)

Fig. 4. Location of the Roztocze communes in the two-dimensional space of total indicators tourism potential (SMTP) and tourism function (SMTF)

Goraj, Modliborzyce, Radecznica, Szastarka, Turobin, Zakrzew (subregion gorajski), Biłgoraj, Sułów, Tereszpol (subregion szczebrzeszyński), Adamów, Jarczów, Krynice, Tarnawatka, Zamość (subregion tomaszowski), Lubycza Królewska, Narol (subregion rawski).

W świetle uzyskanych wyników pod względem rozwoju zjawisk turystycznych na Roztoczu przoduje subregion tomaszowski. W pozostałych subregionach zjawiska te rozwinięte w pojedynczych gminach. Najsłabiej funkcja turystyczna rozwinięta jest w subregionie gorajskim. 


\section{Dyskusja i wnioski}

Zastosowana procedura badawcza pozwoliła na wyróżnienie potencjalnych i funkcjonalnych obszarów turystycznych na Roztoczu. Wpisuje się ona w nurt poszukiwań rozwiązań metodycznych prowadzących do regionalizacji turystycznej. Uzyskane wyniki badań pozwalają znacząco uszczegółowić dotychczasowy obraz przestrzeni turystycznej regionu, prezentowany np. przez Karolczak (2002) i Tuckiego (2009). Należy stwierdzić, że większość analizowanych gmin to potencjalne obszary turystyczne, zróżnicowane pod względem stopnia rozwoju. Zaledwie jedną trzecią można określić jako turystyczne obszary funkcjonalne.

Uzyskane w efekcie studiów zróżnicowanie stopnia rozwoju zjawisk turystycznych w regionie oraz wyodrębnienie elementów, które o tym decydują, mogą mieć wymiar praktyczny. Wskazują bowiem na kierunki działań, które należy podjąć w odniesieniu do składowych potencjału i funkcji w poszczególnych gminach. Wyróżnienie potencjalnych i funkcjonalnych obszarów turystycznych na Roztoczu, z zastosowaniem metody wielowymiarowej analizy porównawczej, pozwoliło także na określenie istotnych problemów natury metodycznej. Okazało się, że z punktu widzenia jakości i interpretacji wyników, istotne są: pole podstawowe; dobór cech; rzetelna inwentaryzacja elementów uwzględnianych w obliczeniach; łączenie badań ilościowych z jakościowymi; stosowanie jednolitych metod statystycznych do klasyfikowania danych; skala obszaru badań; wykorzystanie technik i narzędzi GIS.

Zagadnienie doboru pól podstawowych w sposób istotny wpływa na porównywalność rezultatów badań. $Z$ problemem tym zetknęli się autorzy wielu wcześniejszych regionalizacji turystycznych Polski, jak również regionalizacji odnoszących się do poszczególnych krain geograficznych. W tym kontekście badacze podkreślali umowny przebieg granic regionów.

Z punktu widzenia wyróżniania obszarów turystycznych ważny jest dobór pól o kompleksowej wartości merytorycznej oraz jednakowej wielkości. Wyniki kwerendy literatury przedmiotu wskazują, że do powyższych wydzieleń stosowane są zarówno regularne pola wieloboczne (m.in. Gajda 1929), jak i pola o kształcie koła (Thauer 1955). Zalety i wady stosowania jednostek fizycznogeograficznych, administracyjnych oraz figur geometrycznych płaskich przeanalizowała m.in. Sołowiej (1987).

W obecnych regionalizacjach turystycznych najczęściej przyjmuje się gminę jako przestrzenne pole odniesienia (m.in. Gołembski 2002; Włodarczyk 2003), co jest uwarunkowane dostępnymi porównywalnymi źródłami danych. Analiza zjawisk w gminach jako polach podstawowych sprawia jednak, że pojawiają się kolejne trudności metodyczne. W niektórych bowiem przypadkach, mimo zastosowania odpowiedniej metody (wskaźniki względne), wielkość powierzchni jednostki decyduje o ostatecznej wartości obliczanego wskaźnika. Dobrym tego przykładem w niniejszym opracowaniu jest gmina Bełżec, dla której uzyskane wskaźniki SMPT i SMFT są najwyższe przy najmniejszej jej powierzchni. 
Wartości obliczonych wskaźników w granicach gmin jako pól podstawowych są uśrednione. Nie oddają one zatem rzeczywistego rozmieszczenia analizowanych cech, m.in. zasobów turystycznych, natężenia i kierunków ruchu turystycznego, które mogą występować w różnych układach przestrzennych, np. liniowych, punktowych. Istotne jest więc dalsze poszukiwanie metod, które pozwolą na uzyskanie obiektywnego obrazu wyników badań odniesionych do porównywalnych powierzchni pól podstawowych.

$\mathrm{Z}$ wyborem pola podstawowego wiąże się problem doboru cech do analizy potencjału i funkcji turystycznej. Uzyskane wyniki wskazują na konieczność przyjmowania jednakowej liczby cech określających potencjał i funkcję, w celu uzyskania szczegółowego i obiektywnego obrazu funkcjonowania zjawisk turystycznych. Na przykład skupienie ruchu turystycznego o dużym natężeniu tylko w jednym obiekcie może wpływać na wysoki wskaźnik funkcji turystycznej odnoszący się do powierzchni obszaru. Daje to odbiorcy fałszywy obraz funkcjonowania zjawiska w przyjętych jego granicach. Na Roztoczu takim przykładem jest gmina Bełżec o wysokim SMPT, związanym z funkcjonowaniem tylko jednego obiektu.

Wśród składowych potencjału turystycznego istotna jest także skuteczność promocji ofert turystycznych. Złożonym problemem jest sposób jej oceny. Powinno się przy tym brać pod uwagę nie tylko liczbę ofert promowanych poprzez media i/lub inne materiały reklamowe, ale także ich oddziaływanie na turystę, wyrażone najczęściej wzrostem wielkości ruchu turystycznego.

Kolejnym problemem jest ilościowe (bezwzględne) traktowanie cech stanowiących potencjał. Nie zawsze liczba walorów/obiektów stanowi o ich atrakcyjności dla turystów. Wiele spośród przyjmowanych cech ma charakter zasobów (np. rezerwat przyrody odpowiednio przygotowany dla turystów jest walorem, a niedostępny dla turystów - jest zasobem bez szans na rozwój). Istotne jest zatem wypracowanie jednolitego sposobu oceniania przydatności cech dla turystycznego wykorzystania.

Nieodłącznym elementem rozwoju funkcji turystycznej obszarów są produkty turystyczne. W większości opracowań nie ujmuje się ich jednak jako składowych funkcji. Być może jest to związane z zakresem pojęciowym (np. jak traktować muzeum - czy jest walorem, czy produktem?), kwestią dostępności źródeł danych, dużą zmiennością ich funkcjonowania w czasie. Z oceną funkcji turystycznej wiążą się także trudności w określeniu realnego ruchu turystycznego. Sprecyzowanie jego wielkości wymaga bardzo żmudnych i długotrwałych badań terenowych, ale niekiedy w ogóle nie jest możliwe ze względu na poufność danych, która obowiązuje podmioty turystyczne. Kolejnym problemem jest rozróżnienie, kto jest turystą, a kto odwiedzającym.

Od wyników rzetelnej inwentaryzacji elementów uwzględnianych w obliczeniach zależne są uzyskiwane wielkości potencjału i funkcji. Zadanie to jest bardzo trudne do wykonania, zwłaszcza w regionach wielkopowierzchniowych. $Z$ punktu widzenia oceny elementów potencjału i funkcji ważne jest łączenie badań ilościowych 
z jakościowymi. W procedurach dotyczących niektórych składowych konieczne jest uwzględnienie wyników badań nad percepcją zasobów turystycznych przez użytkowników. Określenie jakości i poprawna interpretacja wyników, zależą w dużym stopniu od zastosowania jednolitych metod statystycznych, zwłaszcza do wydzielania przedziałów klasowych.

Kolejnym czynnikiem wpływającym na obiektywność otrzymywanych wyników jest skala obszaru badań. $Z$ nim związana jest zmiana poziomu agregacji danych im mniejsze jednostki podziału, tym obraz przestrzennego zróżnicowania zjawisk jest bardziej zróżnicowany. Zdaniem Leonowicza (2006) przyjęcie większych jednostek odniesienia prowadzi do uogólnienia treści i uśrednienia wartości zjawisk (zmniejsza się rozpiętość przedstawianych danych). Zatem wnioski, formułowane na podstawie danych odniesionych do jednostek przestrzennych, są słuszne tylko dla określonego poziomu agregacji przestrzennej. W przypadku Roztocza uzyskane wnioski są więc prawdziwe dla analizowanych gmin jako obszarów turystycznych. Ponadto do prezentacji zjawisk turystycznych w ujęciu przestrzennym istotne jest stosowanie nowoczesnych technik i narzędzi GIS. Umożliwiają one dokładne odwzorowanie zjawisk w przestrzeni, a następnie ich agregację w obszarach o różnym wymiarze (zasięg i rodzaje granic, w tym problem nakładania się różnych typów granic - administracyjnych, fizycznogeograficznych).

Jak pokazują przeprowadzone badania, a także dyskusja wyników, podjęty w opracowaniu problem delimitacji regionów turystycznych nadal pozostaje nierozwiązany metodologicznie i aktualny. Wymaga on dalszych prób, zwłaszcza z wykorzystaniem rosnących możliwości zastosowania nowoczesnych technik i narzędzi badawczych oraz łączenia różnych podejść koncepcyjnych.

\section{Literatura}

Bajcar A., 1969a, Regiony turystyczne Polski. C\&. I, Geografia w Szkole, 3, 122-133.

Bajcar A., 1969b, Regiony turystyczne Polski. Cz. II, Geografia w Szkole, 4, 202-210.

Bański J., Stola W., 2002, Przemiany struktury przestrzennej i funkcjonalnej obszarów wiejskich w Polsce, Studia Obszarów Wiejskich, 2, PTG, IGiPZ PAN, Warszawa.

Bar R., Doliński A., 1976, Geografia turystyczna, WSiP, Wrocław.

Bartkowski T., 1979, Podstawowe elementy teorii oceny atrakcyjności geokompleksu dla rekreacji a róśne etapy i poziomy planowania, [w:] Ocena atrakcyjności srodowiska geografičnego dla potrzeb turystyki i rekreacji na róśnych poziomach i etapach planowania. Materiały konferencji naukowej, Poznań, dnia 19 i 20 listopada 1977 r. / Akademia Wychowania Fizycznego w Poznaniu, Monografie AWF w Poznaniu, 116.

Bartkowski T., 1980, Warunki fizjograficzne pokonywania præestrzeni w turystyce jako przedmiot badań, [w:] Metodologia badań w turystyce, Monografie AWF w Poznaniu, 129.

BDL, 2016, Bank Danych Lokalnych, http://stat.gov.pl/bdl (20.08.2016). 
Brzezińska-Wójcik T., Skowronek E., Świeca A., 2016, Roztocze - od krainy fizjograficznej do regionu turystycznego, [w:] T. Brzezińska-Wójcik, E. Skowronek, A. Świeca (red.), Od regionu geograficznego do regionu turystycznego. Lubelszczyzna - implikacje historyczne, teoretyczne, naukowo-badawcze, edukacyjne, Wydawnictwo UMCS, Lublin, 133-168.

Buraczyński J., 1995, Regiony geomorfologiczne Roztocza, Annales UMCS, B, 48 (1993), 59-73.

Cabaj W., Kruczek Z., 2007, Podstawy geografii turystycznej, „Proksenia”, Kraków.

Deja W., 1982, Problemy regionalizacji turystycznej, [w:] Regionaliæacja turystyczna Polski, Monografie AWF w Poznaniu, 201, 39-49.

Derek M., 2008, Funkcja turystyczna jako czynnik rozwoju lokalnego w Polsce, rozprawa doktorska wykonana pod kierunkiem prof. dr. hab. Andrzeja Kowalczyka, Wydział Geografii i Studiów Regionalnych UW, Warszawa, http://www.zripl.uw.edu.pl/uploads/f_turyzm/1_pdfsam_doktorat\%20w\%20pdf.pdf (22.01.2016).

Durydiwka M., 2012, Cæynniki rozwoju i zró:nicowanie funkcji turystycะnej na obszarach wiejskich w Polsce, Wydział Geografii i Studiów Regionalnych UW, Warszawa.

Evans I.S., 1977, The selection of class intervals, Transactions, Institute of British Geographers, New Series, 2 (1), 98-124.

Filipowicz Z., 1969, Problemy ekonomiczne turystyki, Sport i Turystyka, Warszawa.

Gajda R., 1929, Wysokości waględne w kotlinie Nidy, Wiadomości Geograficzne, 7 (5), 63-64.

Gołembski G. (red.), 1999, Regionalne aspekty rozwoju turystyki, Wydawnictwo Naukowe PWN, Warszawa-Poznań.

Gołembski G. (red.), 2002, Metody stymulowania rozwoju turystyki w ujęciu przestrzennym, Wydawnictwo Akademii Ekonomicznej, Poznań.

Jackowski A., 1981, Typologia funkcjonalna miejscowości turystycznych (na przykładzie wojewódætwa nowosqdeckiego), Rozprawy Habilitacyjne, 53, Wydawnictwo Uniwersytetu Jagiellońskiego, Kraków.

Jafari J. (red.), 2001, Encyclopedia of tourism, Routledge, London-New York.

Kaprowski W., 2004, Geografia turystyczna, WSE, Warszawa.

Karolczak M., 2002, Præestrzeń turystyczno-wypoczynkowa Roztocza, Turyzm, 1, 5-36.

Kondracki J., 1960, Typy krajobrazu naturalnego (środowiska geograficznego) w Polsce, Przegląd Geograficzny, 32, (1/2), 23-33.

Kondracki J., 1965, Geografia fizyczna Polski, PWN, Warszawa.

Kruczek Z., 2003, Regiony turystyczne Polski. Problemy ich delimitacji i funkcjonowania, Problemy Turystyki i Hotelarstwa, 4 (8), 6-14.

Kruczek Z., Sacha S., 1977, Geografia turystyczna Polski. Poradnik, Polskie Towarzystwo Ekonomiczne, Kraków.

Kruczek Z., Zmyślony P., 2010, Regiony turystyczne, „Proksenia”, Kraków.

Leonowicz A.M., 2006, Kartogram jako forma prezentacji «ależności æjawisk geograficznych, Prace Geograficzne IGiPZ PAN, 206.

Leszczycki S., 1937, Les régions de l'industrie balnéaire et tourist ique en Pologne. Bilan du tourisme des villes de cure en Pologne, Acta Balneologica Polonica, I, (2), 20-25. 
Leśko R., Klementowski K., 1979, Rejonizacja turystyczna (uwzględniajqca nowy podziat administracyjny) ora: określenie zasobów turystyc nych podstawowych jednostek gospodarki præestræennej w turystyce, Biuletyn Informacyjny Instytutu Turystyki, 1, 9-13.

Lijewski T., Mikułowski B., Wyrzykowski J., 1985, Geografia turystyki Polski, PWE, Warszawa. Liszewski S., 2003, Region turystyczny, Turyzm, 13 (1), 43-54.

Liszewski S., 2008, Ewolucja pogladów na temat regionu turystycznego. Od regionu krajoznawczego po funkcjonalny, [w:] G. Gołembski (red.), Turystyka jako czynnik warostu konkurencyjności regionów w dobie globalizacji, Akademia Ekonomiczna, Poznań, 127-135.

Liszewski S., 2009, Przestræen turystyczna Polski. Koncepcja regionalizacji turystycznej, Folia Turistica, 21, 17-30.

Matczak A., 1989, Problemy badania funkcji turystycznej miast Polski, Acta Universitatis Lodziensis, Turyzm, 5, 27-39.

Matczak A., 1995, Stan wiedzy w regionie, [w:] Studium wiedzy o regionie tódzkim. Rozwój turystyki w regionie tódzkim, Łódzkie Towarzystwo Naukowe, Łódź, 166-201.

Mazur E., 2005, Geografia turystyczna, Wydawnictwo Naukowe Uniwersytetu Szczecińskiego, Szczecin.

Mileska M.I., 1963, Regiony turystyczne Polski. Stan obecny i potencjalne warunki rozwoju, Prace Geograficzne, 43, 7-156.

Naumowicz K., 1993, Potencjat turystyczny i regionalizacja turystyczna Polski, Uniwersytet Szczeciński, Rozprawy i Studia, t. CCX 136, Szczecin.

Pasławski J., 2003, Jak opracować kartogram, Wydział Geografii i Studiów Regionalnych UW, Warszawa.

Plan kierunkowy zagospodarowania turystycznego Polski, 1971, Główny Komitet Kultury Fizycznej i Turystyki i Instytut Turystyki, Warszawa.

Pociecha J., 2008, Rozwój metod taksonomicznych $i$ ich sastosowań w badaniach spoteczno-ekonomicznych, http://www.stat.gov.pl/cps/rde/xbcr/gus/ (2.02.2017).

Pociecha J., Podolec B., Sokołowski A., Zając K., 1988, Metody taksonomicæne w badaniach spoteczno-ekonomicznych, PWN, Warszawa.

Ptaszycka-Jackowska D., 2007, Gospodarowanie przestrzeniq turystycznq w Polskich Karpatach, Prace Geograficzne UJ, 117, 99-112.

Sobotka S., 2014, Próba wyznaczenia obszarów o najwy:szym stopniu wykorzystania turystycznego jako przestanki do regionalizacji turystycznej Polski, Turyzm, 24 (2), 35-43.

Sołowiej D., 1987, Podstawy metodyki oceny środowiska przyrodniczego człowieka, Wydawnictwo Naukowe UAM, Poznań.

Świeca A., Brzezińska-Wójcik T., Skowronek E., Krukowska R., Tucki A., Grabowski T., Malska M., Zinko J., Brusak V., Pandiak I., Shevchuk O. 2015, Turystyka na Roztoczu, [w:] T. Grabowski, M. Harasimiuk, B.M. Kaszewski, Y. Kravchuk, B. Lorens, Z. Michalczyk, O. Shabliy (red.), Roztocze-przyroda i cztowiek, Roztoczański Park Narodowy, Zwierzyniec, 391-427.

Thauer W., 1955, Neue Methoden der Berechnung und Darstellung der Reliefenergie, Petermanns Geographische Mitteilungen, 1, 8-13. 
Tucki A., 2009, Propozycja regionalizacji turystycznej województwa lubelskiego, Folia Turistica, $21,145-164$.

Tucki A., Świeca A., 2008, Rola samorzqdów lokalnych w rozwoju turystyki na przyktadzie regionu lubelskiego, [w:] J. Wyrzykowski (red.), Uwarunkowania rowwoju turystyki \&agranicznej w Europie Środkowej $i$ Wschodniej, 10, Turystyka w środowisku geograficznym, Instytut Geografii i Rozwoju Regionalnego Uniwersytetu Wrocławskiego, Wrocław, 497-512.

Warszyńska J., Jackowski A., 1979, Podstawy geografii turyzmu, PWN, Warszawa.

Włodarczyk B., 2003, Potencjat turystyczny, [w:] S. Liszewski (red.), Moふ̇liwości i kierunki rozwoju turystyki w Dolinie Odry, Katedra Geografii Miast i Turyzmu UŁ, Łódzkie Towarzystwo Naukowe, Łódź, 215-226.

Wyrzykowski J., 1975, Walory wypoczynkowe środowiska pryyrodniczego Polski w świetle aktualnego stanu badań, Zeszyty Naukowe Instytutu Turystyki, 2 (2/3), 25-44.

Wyrzykowski J., 1986, Geograficæne wwarunkowania rozwoju urlopowej turystyki wypoczynkowej w Polsce, Acta Universitatis Wratislaviensis, 935, Studia Geograficzne, 44.

Zawilińska B., 2005, Karpaty jako region turystyczny, [w:] Z. Górka, J. Więcław-Michniewska (red.), Badania i podróże naukowe krakowskich geografów, 2, PTG Oddział w Krakowie, Kraków, 144-152.

http://www.zamosc.pttk.pl/wordpress/?page_id=7804 (4.02.2017).

Autorki dziękują anonimowym Recenzentom za cenne uwagi, które wpłynęły na ostateczną wersję artykułu. Wyniki badań w publikacji są efektem prac w ramach statutowego zadania badawczego „Uwarunkowania rozwoju różnych form turystyki na wybranych obszarach" nr BS-P-12-011-17-S-01.

\author{
Teresa Brzezińska-Wójcik \\ Uniwersytet Marii Curie-Sktodowskiej \\ Wydziat Nauk o Ziemi i Gospodarki Przestrzennej \\ al. Kraśnicka 2d, 20-718 Lublin \\ tbrжezin@pocsta.umcs.lublin.pl \\ Ewa Skowronek \\ Uniwersytet Marii Curie-Sktodowskiej \\ Wydziat Nauk o Ziemi i Gospodarki Przestrzennej \\ al. Kraśnicka 2d, 20-718 Lublin \\ ewa.skowronek@pocsta.umcs.lublin.pl
}


